\title{
PERBANDINGAN PROSES DEKONTAMINASI TERMOMETER ANTARA PENGGUNAAN ALKOHOL 70\% DENGAN LARUTAN KLORIN, AIR SABUN DAN AIR DTT PADA IBU HAMIL TRIMESTER III DI KELURAHAN SETIAWARGI KECAMATAN TAMANSARI KOTA TASIKMALAYA PERIODE NOPEMBER-DESEMBER TAHUN 2013
}

Oleh :

Meti Megawati' ${ }^{1}$ Mimma Fatmala ${ }^{2}$, alamat surel: meti.megawati81@gmail.com

\section{A. Abstrak}

Studi yang dilakukan WHO di 55 rumah sakit di 14 negara diseluruh dunia juga menunjukkan bahwa (8,7\%) pasien rumah sakit menderita infeksi selama menjalani perawatan di rumah sakit. Sementara di Negara berkembang, diperkirakan lebih dari (40\%) pasien di rumah sakit terserang infeksi nosokomial. Penelitian yang dilakukan di 11 rumah sakit di DKI Jakarta pada tahun 2010 menunjukkan bahwa (9,8\%) pasien rawat inap mendapat infeksi yang baru selama di rawat. Tingginya frekuensi kontak dengan darah penderita akan meningkatkan risiko terjadinya infeksi pada tenaga kesehatan. Penelitian yang dilakukan terhadap 24.000 tenaga kesehatan di rumah sakit selama 3 tahun menunjukkan bahwa insiden kontak darah (exposure rate) 3,5 per 100 pekerja per tahun. Studi awal yang dilakukan peneliti pada bulan September tahun 2013 dengan melakukan wawancara terbuka kepada Bidan Kelurahan Setiawargi Kecamatan Tamansari Kota Tasikmalaya diperoleh informasi bahwa masih ada kejadian cross infection yang terjadi pada ibu hamil yang disebabkan karena penggunaan alat-alat yang tidak steril, dalam hal ini penggunaan termometer. Tujuan penelitian ini untuk mengetahui perbandingan proses dekontaminasi termometer antara yang menggunakan Alkohol 70\% dengan Larutan Klorin, Air Sabun dan Air DTT pada ibu hamil trimester III di Kelurahan Setiawargi Kecamatan Tamansari Kota Tasikmalaya.

Jenis penelitian yang digunakan adalah eksperimen, dengan rancangan acak lengkap. Penelitian ini telah dilaksanakan di Kelurahan Setiawargi Kecamatan Tamansari Kota Tasikmalaya, pada bulan Desember Tahun 2013. Besar sampel sebanyak 2 orang yang diambil dengan teknik Purposive Sampling. Instrumen penelitian ini menggunakan termometer yang telah dikalibrasi, lembar observasi, media agar dan mikroskop.

Hasil Penelitian menunjukkan bahwa termometer baru yang akan digunakan terdapat bakteri jumlah bakteri setelah digunakan pada ketiak ibu hamil trimester III responden A pada temp 1 sebanyak $1077 \mathrm{koloni} / \mathrm{cm}^{2}$ dan temp 2 sebanyak $1923 \mathrm{koloni} / \mathrm{cm}^{2}$. Sedangkan pada ibu hamil trimester III responden B pada temp 1 sebanyak $4619 \mathrm{koloni} / \mathrm{cm}^{2}$ dan pada temp II sebanyak $1000 \mathrm{koloni} / \mathrm{cm}^{2}$. Terdapat perbedaan yang signifikan proses dekontaminasi termometer antara yang menggunakan alkohol $70 \%$ dengan larutan klorin, air sabun, dan air DTT pada ibu hamil trimester III di Kelurahan Setiawargi Kecamatan Tamansari Kota Tasikmalaya periode Nopember-Desember tahun 2014 ( $p=0,04)$. Direkomendasikan petugas kesehatan/ bidan dalam mensterilkan alat-alat kesehatan dapat menggunakan alkohol 70\%, karena dapat efektif menghilangkan bakteri, serta membuat SOP nya.

Kata Kunci: Dekomentasi, Alkohol 70\%, Larutan Klorin, Air Sabun, Air DTT 


\section{B. Latar Belakang}

Sterilisasi merupakan suatu proses untuk membunuh semua jasad renik yang ada sehingga jika ditumbuhkan dalam suatu media tidak ada jasad renik yang dapat berkembang biak. Sterilisasi harus dapat membunuh jasad renik yang paling tahan panas yaitu spora bakteri. Sterilisasi termometer yang sudah digunakan sangat penting dilakukan, agar bakteri yang ada pada termometer dapat dihilangkan. Pada kenyataannya bakteri yang menempel pada termometer sulit untuk dihilangkan, hal ini akan berdampak pada penyebaran bakteri pada orang yang menggunakan termometer tersebut.

Apabila proses pembersihan atau sterilisasi tidak adekuat, dan termometer yang telah terkontaminasi itu digunakan pada orang lain yang berbeda, maka dapat terjadi penyebaran dari suatu penyakit atau cross infection terhadap orang tersebut, seperti bacterial endocarditis, herpes, hepatitis B, hepatitis C, dan HIV. Penyakitpenyakit tersebut memiliki tingkat resiko kematian yang tinggi, karena itu harus dilakukan upaya pencegahan terjadinya cross infection pada orang lain. Dalam bidang kedokteran ataupun kebidanan prosedur kontrol infeksi harus selalu dilakukan dengan tepat untuk menghindari terjadinya (cross infection). Terdapat kelebihan dan kekurangan dari berbagai macam sterilisasi, sehingga dibutuhkan pengetahuan dari tenaga kesehatan dalam melakukan sterilisasi terhadap alat-alat yang digunakan, dan juga harus selalu dilakukan maintenance terhadap alat tersebut sehingga dapat memberikan hasil sterilisasi yang optimal.

World Health Organization memperkirakan pada tahun 2010 akan terjadi 16.000 kasus penularan hepatitis $\mathrm{C}$, 66.000 kasus penularan hepatitis B dan 1000 kasus penularan HIV pada tenaga kesehatan di seluruh dunia. Studi yang dilakukan WHO di 55 rumah sakit di 14 negara diseluruh dunia juga menunjukkan bahwa $(8,7 \%)$ pasien rumah sakit menderita infeksi selama menjalani perawatan di rumah sakit.
Sementara di Negara berkembang, diperkirakan lebih dari (40\%) pasien di rumah sakit terserang infeksi nosokomial.

Penelitian yang dilakukan di 11 rumah sakit di DKI Jakarta pada tahun 2010 menunjukkan bahwa $(9,8 \%)$ pasien rawat inap mendapat infeksi yang baru selama di rawat. Tingginya frekuensi kontak dengan darah penderita akan meningkatkan risiko terjadinya infeksi pada tenaga kesehatan. Penelitian yang dilakukan terhadap 24.000 tenaga kesehatan di rumah sakit selama 3 tahun menunjukkan bahwa insiden kontak darah (exposure rate) 3,5 per 100 pekerja per tahun.

Banyak penelitian telah dilakukan untuk mencari cara yang paling efektif dalam membersihkan instrumen alat yang digunakan, penelitian Letters et al yang membuktikan bahwa ternyata masih ditemukan adanya sisa debris pada endodintic files walaupun telah dilakukan pembersihan dengan ultrasonic cleaning. Tidak jauh berbeda dengan penelitian yang dilakukan oleh Whitworth et al menunjukkan kegagalan autoclave dalam membersihkan darah dan saliva pada dental bur, dan juga tidak menghilangkan bakteri yang mengkontaminasi bur tersebut.

Penelitian lain yang berhubungan dengan sterilisasi juga pernah dilakukan oleh Adji dkk (2007) yang menyatakan bahwa Bacillus subtilis masih tetap tumbuh dengan dibersihkan oleh alkohol $70 \%$. Sterilisasi dengan inframerah menunjukkan tidak ada pertumbuhan bakteri Bacillus subtilis. Sterilisasi dengan autoclave satu sampel positif tumbuh sedangkan dua sampel yang lain negatif (bakteri tidak tumbuh), dan sterilisasi dengan ozon menunjukkan Bacillus subtilis tetap tumbuh. Dari penelitian ini disimpulkan bahwa sterilisasi menggunakan inframerah adalah yang paling efektif diantara metoda sterilisasi yang lain.

Penelitian serupa pernah diteliti oleh Andriyani (2009) menerangkan bahwa ada pengaruh larutan detergent dan larutan klorin pada proses pencucian alat makan dengan metode three compartement sink 
dalam menurunkan jumlah angka kuman alat makan di Rumah Sakit PKU Muhammadiyah Surakarta. Faktor yang memungkinkan terjadinya penularan penyakit di rumah sakit adalah adanya sumber penyakit, dalam hal ini pasien merupakan sumber penyakit. Kontaminasi silang adalah kontaminasi dari bahan makanan melalui pembawa dalam hal ini lewat alat makan, terutama sendok.

Ibu hamil trimester III sering mengalami banyak keluar keringat baik pada siang hari maupun malam hari, keadaan ini sering mengganggu dan membuat tidak nyaman, dalam sehari ibu hamil bisa mandi lebih dari dua kali untuk mengatasi rasa panas dan keringat yang berlebih tadi. Ternyata rasa panas dan keringat berlebih adalah biasa terjadi pada saat hamil. Efek yang ditimbulkan dari banyaknya keringat yang keluar dari tubuh ibu hamil dapat menyebabkan terjadinya

\section{Metode}

Jenis penelitian yang digunakan adalah eksperimen, dengan rancangan acak lengkap. Penelitian ini telah dilaksanakan di Kelurahan Setiawargi Kecamatan Tamansari Kota Tasikmalaya, pada bulan Desember Tahun 2013.

Besar sampel sebanyak 2 orang yang diambil dengan teknik Purposive Sampling, dengan kriteria inklusi dan eksklusi, sebagai berikut :

1. Kriteria inklusi

a. Ibu hamil trimester III

b. Berada di wilayah tempat penelitian

c. Bersedia menjadi responden

2. Kriteria eksklusi

a. Ibu hamil trimester III yang

b. Mengalami alergi pada kulit

c. Personal hygienenya kurang.

Penelitian ini terdiri dari variabel bebas dan variabel terikat. Variabel independent (bebas) meliputi: Dekontaminasi (alkohol 70\%, larutan klorin, air sabun, dan DTT), variabel dependent (terikat) adalah kehilangan bakteri pada termometer. penyakit atau iritasi kulit karena kulit basah lebih rentan terhadap infeksi bakteri dan jamur tambahan.

Studi awal yang dilakukan peneliti pada bulan September tahun 2013 dengan melakukan wawancara terbuka kepada Bidan Kelurahan Setiawargi Kecamatan Tamansari Kota Tasikmalaya diperoleh informasi bahwa masih ada kejadian cross infection yang terjadi pada ibu hamil yang disebabkan karena penggunaan alat-alat yang tidak steril, dalam hal ini penggunaan termometer.

Berdasarkan fenomena tersebut, penulis tertarik untuk melakukan penelitian mengenai " Perbandingan Proses Dekontaminasi Termometer Antara Yang Menggunakan Alkohol 70\% dengan Larutan Klorin, Air Sabun dan Air DTT Pada Ibu Hamil Trimester III di Kelurahan Setiawargi Kecamatan Tamansari Kota Tasikmalaya Periode Nopember-Desember Tahun 2013”.

Instrumen penelitian ini menggunakan termometer yang telah dikalibrasi, lembar observasi, media agar dan mikroskop untuk melihat kehilangan bakteri yang disebabkan karena perlakuan atau eksperimen.

Cara pengambilan data pada penelitian ini adalah melakukan informed consent, melakukan prosedur pembersihan ketiak dengan menggunakan tissue kering. Sebelum diberikan perlakuan, termometer yang akan digunakan terlebih dahulu disterilisasi dan dikulturisasi pada media agar, dengan tujuan agar termometer yang digunakan benar-benar bersih dari mikroorganisme.

Termometer yang sudah bersih digunakan untuk mengukur suhu pada ketiak klien. Masing-masing klien mendapat perlakuan sebanyak 2 kali perlakuan dengan termometer yang berbeda. Setelah digunakan kemudian termometer tersebut disterilisasi sesuai dengan perlakuan penelitian. Selanjutnya kedua termometer tersebut dilakukan kulturisasi pada media agar untuk bisa dilihat jumlah bakteri oleh mikroskop keesokan harinya. 
Data yang telah diambil kemudian dianalisis dengan menggunakan analisis univariat untuk mendeskripsikan hasil pengukuran masing-masing variabel.

\section{Hasil Penelitian}

Penelitian tentang perbandingan kehilangan bakteri pada termometer antara yang menggunakan alkohol $70 \%$ dengan larutan klorin, air sabun dan air DTT telah dilaksanakan pada 2 orang ibu hamil di Kelurahan Setiawargi Kecamatan Tamansari Kota Tasikmalaya pada bulan Desember tahun 2013. Hasil penelitian ini terdiri dari analisis univariat dan analisis bivariat, yang akan dijelaskan sebagai berikut :

1. Analisis Univariat
Sedangkan untuk menghubungkan antara variabel dependen dan independen digunakan analisis bivariat dengan Uji $t$-test.

Analisis univariat digunakan untuk mendeskripsikan atau menggambarkan variabel-variabel yang diteliti, dalam penelitian ini mengenai kehilangan bakteri pada termometer antara yang menggunakan alkohol $70 \%$ dengan larutan klorin, air sabun dan air DTT. Hasil penelitian akan diuraikan sebagai berikut :

a. Jumlah Bakteri pada Termometer Sebelum Digunakan

Jumlah bakteri pada termometer baru sebelum digunakan pada ibu hamil dapat dilihat pada tabel di bawah ini :

Tabel 4.1

Jumlah Bakteri pada Termometer Baru Sebelum Digunakan pada Ibu Hamil Trimester III

\begin{tabular}{|c|c|}
\hline Jumlah Termometer & Jumlah bakteri \\
\hline Temp 1 & 2 \\
\hline Temp 2 & 1 \\
\hline Temp 3 & 1 \\
\hline Temp 4 & 1 \\
\hline
\end{tabular}

Berdasarkan Tabel 4.1 menunjukkan bahwa termometer baru yang akan digunakan terdapat bakteri yaitu pada temp 1 terdapat 2 bakteri, sedangkan pada temp 2,3 dan 4 masing-masing terdapat 1 bakteri. b. Jumlah Bakteri pada Termometer Setelah Digunakan pada Ketiak Ibu Hamil Trimester III

Jumlah bakteri pada termometer setelah digunakan pada ketiak ibu hamil trimester III dapat dilihat pada tabel berikut ini :

Tabel 4.2

Jumlah Bakteri pada Termometer Setelah Digunakan pada Ketiak

Ibu Hamil Trimester III di Kelurahan Setiawargi

Kecamatan Tamansari Kota Tasikmalaya

Periode Nopember-Desember

Tahun 2013

\begin{tabular}{|c|c|c|}
\hline \multicolumn{2}{|c|}{ Responden } & Jumlah Bakteri \\
\hline \multirow{2}{*}{ A } & Temp 1 & 1077 \\
\cline { 2 - 3 } & Temp 2 & 1923 \\
\hline \multirow{2}{*}{ B } & Temp 1 & 4619 \\
\cline { 2 - 3 } & Temp 2 & 1000 \\
\hline
\end{tabular}


Sumber : Data Hasil Penelitian (2013) (Hasil Perhitungan Jumlah Bakteri dapat Dilihat pada Lampiran

Berdasarkan Tabel 4.2 menunjukkan bahwa jumlah bakteri setelah digunakan pada ketiak ibu hamil trimester III responden A pada temp 1 sebanyak 1077 koloni $/ \mathrm{cm}^{2}$ dan temp 2 sebanyak 1923 koloni $/ \mathrm{cm}^{2}$. Sedangkan pada ibu hamil trimester III responden B pada temp 1 sebanyak 4619 koloni $/ \mathrm{cm}^{2}$ dan pada temp II sebanyak $1000 \mathrm{koloni} / \mathrm{cm}^{2}$.

c. Jumlah Kehilangan Bakteri pada Termometer dengan Menggunakan Alkohol 70\% dan Larutan Klorin, Air Sabun, dan Air DTT

Jumlah kehilangan bakteri pada termometer dengan menggunakan alkohol $70 \%$ dan larutan klorin, air sabun, dan air DTT pada ibu hamil trimester III dapat dilihat pada tabel berikut ini :

Tabel 4.3

Kehilangan Bakteri pada Termometer Setelah di Dekontaminasi oleh Larutan Alkohol 70\% dan Larutan Klorin, Air Sabun, dan Air DTT pada Ibu Hamil Trimester III di Kelurahan Setiawargi Kecamatan Tamansari Kota Tasikmalaya Periode NopemberDesember Tahun 2013

\begin{tabular}{|c|c|c|}
\hline \multirow{2}{*}{ Resp } & \multicolumn{2}{|c|}{$\begin{array}{c}\text { Jumlah Kehilangan Bakteri } \\
(\text { Koloni/cm }\end{array}$} \\
\cline { 2 - 3 } & Alkohol $70 \%$ & $\begin{array}{c}\text { Larutan Klorin, Air Sabun, } \\
\text { dan Air DTT }\end{array}$ \\
\hline A & 1071 & 1231 \\
\hline B & 3311 & 115 \\
\hline
\end{tabular}

Berdasarkan Tabel 4.3 menunjukkan bahwa jumlah kehilangan bakteri pada termometer dengan menggunakan alkohol $70 \%$ pada responden A sebanyak 1071 koloni $/ \mathrm{cm}^{2}$ dari jumlah bakteri sebanyak 1077 koloni $/ \mathrm{cm}^{2}$ atau sekitar 99,4\%, sedangkan pada responden $B$ jumlah kehilangan bakteri sebanyak 3311 koloni $/ \mathrm{cm}^{2}$ dari jumlah bakteri sebanyak $4619 \mathrm{koloni} / \mathrm{cm}^{2}$ atau sekitar $71,7 \%$. Jumlah kehilangan bakteri pada termometer dengan menggunakan larutan klorin, air sabun, dan air DTT pada responden A sebanyak 1231 koloni $/ \mathrm{cm}^{2}$ dari jumlah bakteri sebanyak
$1923 \mathrm{koloni} / \mathrm{cm}^{2}$ atau sekitar 64,0\%, sedangkan pada responden B jumlah kehilangan bakteri sebanyak $115 \mathrm{koloni} / \mathrm{cm}^{2}$ dari jumlah bakteri sebanyak 1000 koloni $/ \mathrm{cm}^{2}$ atau sekitar $11,5 \%$.

\section{Analisis Bivariat}

Analisis bivariat digunakan untuk mengetahui perbandingan proses dekontaminasi termometer antara yang menggunakan alkohol $70 \%$ dengan larutan klorin, air sabun, dan air DTT pada ibu hamil trimester III, berikut hasil penelitian dapat dilihat pada tabel di bawah ini :

Tabel 4.4.

Hasil Uji Statistik Perbandingan Proses Dekontaminasi Termometer Antara yang Menggunakan Alkohol 70\% dengan Larutan Klorin, Air Sabun, dan Air DTT pada Ibu Hamil Trimester III

Di Kelurahan Setiawargi Kecamatan Tamansari

Kota Tasikmalaya Periode NopemberDesember Tahun 2013

\begin{tabular}{|c|c|c|c|c|c|c|}
\hline Mean & Std & SE & CI 95\% & t & df & p value \\
\hline 722,8 & 542,7 & 271,3 & $-140,8-1586,3$ & 3,664 & 3 & 0,04 \\
\hline
\end{tabular}


Berdasarkan Tabel 4.4 menunjukkan bahwa t hitung yang diperoleh sebesar 3,664 dengan nilai signifikan sebesar 0,04 , nilai signifikan ini jika dibandingkan dengan nilai $\alpha(0,05)$ maka nilai signifikan lebih kecil dari nilai $\alpha(0,04<0,05)$ yang berarti bahwa $\mathrm{HO}$ ditolak artinya terdapat perbedaan yang

\section{E. Pembahasan}

1. Jumlah Kehilangan Bakteri pada Termometer dengan Menggunakan Alkohol $70 \%$

Berdasarkan hasil penelitian diperoleh jumlah kehilangan bakteri pada responden A sebanyak $1071 \mathrm{koloni} / \mathrm{cm}^{2}$ dari jumlah bakteri sebanyak $1077 \mathrm{koloni} / \mathrm{cm}^{2}$ atau sekitar 99,4\%, sedangkan pada responden B jumlah kehilangan bakteri sebanyak 3311 koloni $/ \mathrm{cm}^{2}$ dari jumlah bakteri sebanyak $4619 \mathrm{koloni} / \mathrm{cm}^{2}$ atau sekitar $71,7 \%$. Hal ini menunjukkan bahwa dekontaminasi bakteri pada termometer dengan menggunakan alkohol $70 \%$ sangat efektif.

Pendapat Larson (1995) bahwa aktivitas alkohol sebagai antimikroba adalah dengan cara mendenaturasi protein bakteri sehingga mengganggu proses metabolisme sel bakteri yang menyebabkan kematian sel bakteri. Alkohol efektif membunuh bakteri Gram positif dan bakteri Gram negatif. Alkohol juga efektif untuk membuhuh jamur. Adapun kadar alkohol yang efektif untuk menghilangkan bakteri berkisar antara $60 \%$ sampai $95 \%$ sehingga kadar larutan yang mengandung kadar alkohol kurang dari $60 \%$ tidak dapat secara efektif membunuh bakteri atau virus yang terdapat pada tangan atau alat kesehatan lainnya.

Alkohol merupakan denaturan protein, suatu sifat yang terutama memberikan antimikrobial pada alkohol. Disarnping itu, alkohol juga merupakan pelarut lipid sehingga dapat merusak membran sel. Alkohol yang umum dipakai untuk sterilisasi adalah alkohol konsentrasi $70 \%$ karena efektif memecah protein yang signifikan proses dekontaminasi termometer antara yang menggunakan alkohol $70 \%$ dengan larutan klorin, air sabun, dan air DTT pada ibu hamil trimester III di Kelurahan Setiawargi Kecamatan Tamansari Kota Tasikmalaya periode NopemberDesember tahun 2014.

ada dalam mikroorganisme. Menurut Rismana (2002) bahwa penggunaan pada proses disinfeksi adalah untuk permukaan yang kecil, tangan dan kulit. Adapun keunggulan golongan alkohol ini adalah sifatnya yang stabil, tidak merusak material, dapat dibiodegradasi, cocok untuk kulit dan hanya sedikit menurun aktivasinya bila berinteraksi dengan protein. Sedangkan beberapa kerugiannya adalah beresiko tinggi terhadap api/ledakan dan sangat cepat menguap.

Hasil penelitian ini sejalan dengan penelitian yang dilakukan oleh Ariyanti Dessy dkk (2007) yang menyatakan bahwa terhadap efektivitas anti mikroba dari beberapa merk dagang larutan pembersih tangan (hand sanitizer) yang beredar di daerah Jakarta dan sekitarnya menunjukkan bahwa prosentase pengurangan total bakteri yang terdapat pada tangan para responden rata-rata berkisar antara 93,41\% $-98,93 \%$. Kadar alkohol yang efektif sebagai hand sanitizer berkisar antara $60 \%$ sampai $95 \%$ sehingga kadar larutan hand sanitizer yang mengandung kadar alkohol kurang dari $60 \%$ tidak dapat secara efektif membunuh bakteri atau virus yang terdapat pada tangan atau alat kesehatan lainnya.

2. Jumlah Kehilangan Bakteri pada Termometer dengan Menggunakan Larutan Klorin, Air Sabun dan Air DTT

Berdasarkan hasil penelitian menunjukkan bahwa jumlah kehilangan bakteri pada termometer dengan menggunakan larutan klorin, air sabun, dan air DTT pada responden A sebanyak 1231 koloni $/ \mathrm{cm}^{2}$ dari jumlah bakteri sebanyak $1923 \mathrm{koloni} / \mathrm{cm}^{2}$ atau sekitar 
$64,0 \%$, sedangkan pada responden B jumlah kehilangan bakteri sebanyak 115 koloni $/ \mathrm{cm}^{2}$ dari jumlah bakteri sebanyak $1000 \mathrm{koloni} / \mathrm{cm}^{2}$ atau sekitar $11,5 \%$.

Dekontaminasi dengan menggunakan larutan klorin, air sabun dan air DTT dapat mematikan bakteri yaitu bakteri gram positif, bakteri gram negative dan spora bakteri serta tetap aktif digunakan dalam air yang sadah. Kelemahan desinfeksi larutan klorin, air sabun, dan air DTT adalah dapat menyebabkan korosi pada $\mathrm{pH}$ yang rendah, sedangkan konsentrasi yang diperlukan agar larutan klorin, air sabun, dan air DTT efektif untuk membunuh mikroorganisme adalah 50-100 ppm (part per million) dengan waktu kontak sekitar 1 menit pada suhu minimum $24{ }^{\circ} \mathrm{C}$.

Mekanisme cara senyawa klorin dapat mematikan kuman bakteri yaitu asam hipoklorit yang merupakan senyawa klorin yang paling aktif akan menghambat oksidasi glukosa dalam sel mikroorganisme, dengan cara menghambat enzim-enzim yang terlibat dalam metabolisme karbohidrat. Klorin cair atau natrium hipoklorit dalam air akan terhidrolisis membentuk hipoklorit, selanjutnya asam hipoklorit akan terdisosiasi membentuk ion hydrogen dan hipoklorit . Senyawa klorin lebih aktif bila menggunakan pada $\mathrm{pH}$ rendah, karena keberadaan asam hipoklorit lebih dominan. Akan tetapi perlu diingat bahwa daya korosi senyawa klorin juga akan meningkat pada $\mathrm{pH}$ yang rendah. Pada $\mathrm{pH}$ yang tinggi ion hipoklorit tidak memiliki aktivitas bakterisida, sehingga menurunkan efektivitas disinfesi senyawa klorin (Purnawijayanti, 2001). Hasil penelitian ini sejalan dengan penelitian yang dilakukan oleh Andriyani Annisa (2009) yang menyatakan bahwa rata-rata jumlah angka kuman alat makan sebelum dicuci sebesar $832 \mathrm{koloni} / \mathrm{cm}^{2}$ dan setelah dicuci sebesar 51,1 $\mathrm{koloni} / \mathrm{cm}^{2}$. Ada pengaruh larutan detergent dan larutan klorin pada proses pencucian alat makan dengan metode three compartement sink dalam menurunkan jumlah angka kuman alat makan di Rumah Sakit PKU Muhammadiyah Surakarta.

Berdasarkan uraian tersebut, peneliti berpendapat bahwa disinfektan dengan menggunakan larutan klorin, air detergen, dan air DTT dapat menurunkan jumlah bakteri, tetapi tidak seefektif menggunakan air alkohol, ini terjadi karena larutan klorin, air detergen, dan air DTT dipengaruhi oleh sumber lain penggunaan campuran larutan yang kemungkinan terdapat berbagai jenis bakteri seperti penggunaan air.

3. Perbandingan Proses Dekontaminasi Kehilangan Bakteri pada Termometer Antara yang Menggunakan Alkohol 70\% dengan Larutan Klorin, Air Sabun, dan Air DTT

Berdasarkan hasil uji statistik dengan menggunakan Uji $\mathrm{t}$ diperoleh nilai $\mathrm{t}$ hitung sebesar 3,664 dengan nilai signifikan sebesar 0,04, artinya bahwa terdapat perbedaan yang signifikan proses dekontaminasi termometer antara yang menggunakan alkohol $70 \%$ dengan larutan klorin, air sabun, dan air DTT pada ibu hamil trimester III di Kelurahan Setiawargi Kecamatan Tamansari Kota Tasikmalaya periode Nopember-Desember tahun 2014.

Hasil penelitian setelah dilakukan proses dekontaminasi menggunakan alkohol $70 \%$ pada termometer adalah efektif dimana bakteri dapat hilang, hal ini membuktikan bahwa golongan alkohol efektif untuk membunuh bakteri berspora serta efektif bagi virus non-lipoid karena bakteri dalam bentuk spora lebih tahan terhadap disinfektan, sinar dan terutama terhadap kekeringan, panas dan suhu dingin. Hal ini disebabkan karena dinding spora sedikit banyak impermeabel.

Adanya perbedaan kehilangan bakteri pada termometer antara yang menggunakan alkohol 70\% dengan larutan klorin, air sabun, dan air DTT disebabkan karena alkohol bekerja sebagai antiseptik dengan cara denaturasi dan koagulasi protein sel bakteri. Selain itu turunan alkohol juga menghambat sistem fosforilasi dan efeknya terlihat jelas pada 
mitokondria, yaitu pada hubungan substrat-nikotinamid adenine nukleotida. Turunan fenol berinteraksi dengan sel bakteri melalui proses absorbsi yang melibatkan ikatan hidrogen. Pada kadar rendah terbentuk kompleks protein - fenol dengan ikatan yang lemah dan segera mengalami penguraian, diikuti penetrasi fenol ke dalam sel menyebabkan presipitasi serta denaturasi protein. Pada kadar tinggi fenol menyebabkan koagulasi protein dan sel membran mengalami lisis.

Turunan fenol dapat mengubah permeabilitas membran sel bakteri, sehingga menimbulkan kebocoran konstituen sel yang esensial dan mengakibatkan bakteri mengalami kematian. Hasil penelitian Rahayu (2006), menunjukkan bahwa keampuhan alkohol, etanol $70 \%$ terhadap bakteri penyebab mastitis, yaitu Staphylococcus aureus, cukup besar, yaitu 4 kali kekuatan fenol.

Larutan klorin, air sabun, dan air DTT dapat memberikan efek yang sedikit terhadap kehilangan bakteri pada termometer, hal ini disebabkan karena dekontaminasi yang menggunakan lebih dari satu larutan dapat mengakibatkan kekebalan terhadap bakteri. Larutan yang mengandung lebih dari satu laurat bersifat hydrophobic dan hydrophilic. Fungsi dari hidropobic adalah bekerja melepaskan kotoran yang menempel pada peralatan. Hydropilic berfungsi untuk mengangkat kotoran dari permukaan peralatan sehingga terhindar pembentukan noda baru. Larutan klorin, air sabun, dan air DTT juga bersifat bakterisida yang menghilangkan kuman yang ada, namun demikian campuran 1/4 amonium mempunyai efek yang kecil dalam membunuh E.Coli dan L.innocua.

Senyawa klorin lebih aktif bila menggunakan pada $\mathrm{pH}$ rendah, karena keberadaan asam hipoklorit lebih dominan. Akan tetapi perlu diingat bahwa daya korosi senyawa klorin juga akan meningkat pada $\mathrm{pH}$ yang rendah. Pada $\mathrm{pH}$ yang tinggi ion hipoklorit tidak memiliki aktivitas bakterisida , sehingga menurunkan efektivitas disinfesi senyawa klorin.

Hasil penelitian ini sejalan dengan penelitian yang dilakukan oleh Tridianti Anggia (2012) yang menyatakan bahwa terdapat perbedaan jumlah bakteri yang bermakna antara kelompok kontrol metode sterilisasi dan terdapat satu kelompok dengan perbedaan tidak bermakna, yaitu kelompok alkohol-steam autoclave dengan ultrasonic cleaning bath-steam autoclave. Penelitian ini menunjukkan bahwa bahwa steam autoclave memberikan hasil jumlah bakteri yang paling minimal pada molar band yang telah melalui proses fitting band, sehingga steam autoclave merupakan metode sterilisasi yang terbaik dibandingkan dengan dry heat oven, yang sebelumnya masing-masing kelompok molar band tersebut dilakukan prestrelisasi dengan alkohol dan ultrasonic cleaning bath.

Berdasarkan uraian tersebut peneliti berpendapat, bahwa alkohol $70 \%$ merupakan media yang efektif menekan pertumbuhan bakteri yang terdapat dalam berbagai alat kesehatan dibandingkan dengan larutan klorin, air sabun, dan air DTT, karena golongan alkohol efektif untuk membunuh bakteri berspora serta efektif bagi virus non-lipoid karena bakteri dalam bentuk spora lebih tahan terhadap disinfektan, sinar dan terutama terhadap kekeringan, panas dan suhu dingin. 


\section{F. Simpulan dan Saran \\ Simpulan}

Berdasarkan hasil penelitian dan pembahasan, maka dapat disimpulkan sebagai berikut :

1. Pembilasan termometer dengan menggunakan alkohol $70 \%$ yang telah digunakan oleh ibu hamil di Kelurahan Setiawargi Kecamatan Tamansari Kota Tasikmalaya dapat menurunkan kehilangan bakteri rata-rata sebanyak $2191 \mathrm{koloni} / \mathrm{cm}^{2}$ dari jumlah bakteri 2848 atau sebesar $76,9 \%$

2. Pembilasan termometer dengan menggunakan larutan klorin, air sabun, dan air DTT yang telah digunakan oleh ibu hamil di Kelurahan Setiawargi Kecamatan Tamansari Kota Tasikmalaya dapat menurunkan kehilangan bakteri rata-rata sebanyak 673 koloni $/ \mathrm{cm}^{2}$ dari jumlah bakteri 1461 atau sebesar 76,9\% atau sebesar $46,0 \%$

3. Terdapat perbedaan yang signifikan proses dekontaminasi pada termometer antara yang menggunakan alkohol $70 \%$ dengan larutan klorin, air sabun, dan air DTT pada ibu hamil trimester III di Kelurahan Setiawargi Kecamatan

\section{G. Referensi}

Sari, 2012. Distribusi gen enterotoksin Staphylococcus aureus dari susu segar dan pangan asal hewan. Jurnal Veteriner Vol 10 No 3

Ireland et al, 2003. Medical Microbiology An Introduction to Infectious Diseases. 3rd ed. Connecticut: Appleton\&Lange

Denis, 2011. Food microbiology fundamentals and frontiers. ASM Press. Washington DC

Jawetz, 2005. Mikrobiologi Kedokteran (Medical Microbiology). Alih Bahasa Nugroho E, Maulany RF). Jakarta. Penerbit EGC.

Singh G, 2004. Textbook of Orthodontics. $1^{\text {st }}$ ed. New Delhi. Jaypee Brother Medical Publisher (P) Ltd

Adji dkk, 2007. Perbandingan Efektivitas Sterilisasi Alkohol 70\%, Inframerah,
Tamansari Kota Tasikmalaya dengan nilai t hitung sebesar 3,664 atau nilai signifikan sebesar 0,04 .

\section{Saran}

1. Bagi Pelayanan Kebidanan Hendaknya petugas kesehatan/ bidan dalam mensterilkan alat-alat kesehatan dapat menggunakan alkohol 70\%, karena dapat efektif menghilangkan bakteri.

2. Bagi Puskesmas Tamansari Kota Tasikmalaya

Hendaknya pihak puskesmas dapat membuat prosedur tetap dalam merawat dan membersihkan alat-alat kesehatan, sehingga tidak terjadi cross infection, dan meminimalisasi terjadinya penyakit menular pada orang lain.

3. Bagi Penelitian Kebidanan

Hendaknya penelit-peneliti yang lain, menggali lebih mendalam mengenai faktor-faktor yang berhubungan dengan terjadinya cross infection pada alat-alat kesehatan yang digunakan selama pemeriksaan, dengan menggunakan sampel yang lebih banyak dan metode analisis yang berbeda.

Otoklaf, dan Ozon Terhadap Pertumbuhan Bakteri Bacillus subtilis. Jurnal. Universitas Gadjah Mada Yogyakarta. Diakses 26 September 2013

Andriyani, 2009. Pengaruh Larutan Detergent Dan Larutan Klorin Pada Proses Pencucian Alat Makan Dengan Metode Trhee Compartement Sink Terhadap Penurunan Jumlah Angka Kuman Pada Alat Makan Di RS PKU Muhhamadiyah Surakarta. Sekolah Tinggi Ilmu Kesehatan Aisyiyah Surakarta.

Purnawijayanti, 2007. Sanitasi Higiene dan Keselamatan Kerja dalam Pengelolaan Makanan. Kanisius.

Dwidjoseputro, 2005. Dasar-dasar Mikrobiologi. IKAPI. Penerbit Djambatan. 
Siswandono dan B. Soekardjo. 2000. Kimia Medisinal. Surabaya: Airlangga University Press.

Rahayu, I.D. 2009. Kerugian ekonomi mastitis subklinis pada sapi perah. Fakutas Pertanian Jurusan Peternakan. Universitas Muhammadiyah Malang.

Tridianti A. 2012. Efektifitas Berbagai Metode Sterilisasi Molar Band yang Terkontaminasi Pasca Proses Fitting Band: Uji Hitung Bakteri. FKG. Universitas Indonesia: Jakarta, 2012.

Lee H., Cartwrigth R., Grueser T., Pascall MA 2007. Efficiency of manual dishwashing conditions on bacterial survival on eating utensils. Journal of Food Engineering. V.80 : 885-891.

Rismana, E. 2002. Peneliti Muda di P 3 Teknologi Farmasi dan Medika BPPT Jakarta,http : //www.pikiranrakyat. com/ cetak/1 004 I07 I cal.

Ariyanti, D., dkk. 2007. Uji Efektvitas Antikroba Beberapa Merek Dagang Pembersih Tangan Antiseptik. ISSN : 1693-9883. Majalah Ilmu Kefarmasian, Vol. IV, No. 1, April 2007, 1 - 6. 